\title{
Development of powder based ginger drink: analysis of dehydration kinetics and moisture sorption isotherm
}

\author{
1,* Yeasmin, F., ${ }^{2}$ Hira, N.N., ${ }^{3}$ Rahman, H. and ${ }^{2}$ Islam, M.N. \\ ${ }^{1}$ Department of Agro Product Processing Technology, Jashore University of Science and Technology, \\ Jashore-7408, Bangladesh. \\ ${ }^{2}$ Department of Food Technology and Rural Industries, Bangladesh Agricultural University, Mymensingh - \\ 2202, Bangladesh \\ ${ }^{3}$ Department of Textile Engineering, Jashore University of Science and Technology, Jashore-7408, \\ Bangladesh
}

\begin{abstract}
Article history:
Received: 24 July 2020

Received in revised form: 12 August 2020

Accepted: 8 September 2020

Available Online: 24 January 2021
\end{abstract}

\section{Keywords:}

Sorption isotherm,

Dehydration,

Drying kinetics,

Drink

DOI:

https://doi.org/10.26656/fr.2017.5(1).383

\begin{abstract}
The perishable herb ginger (Zingiber officinale) possesses natural aroma and different biologically active components which are beneficial for our health. This can be dried for preservation in pick season for shelf-life increment. This study studied the analysis of the chemical composition, moisture sorption isotherm, dehydration kinetics of ginger for preservation. Air drying was carried out using a cabinet dryer at different temperatures and thickness. According to the sorption isotherm study, monolayer moisture content (MMC) is higher as per Guggenheim-Anderson-DeBoer (GAB) equation compared to the Brunauer-Emmett-Teller (BET) equation. Drying rate increased with the increase in temperature at constant thickness while the adverse result was found with the increase in thickness at a constant temperature. Then, powder-based drinks were prepared by using five different percentages of ginger. The preferences of consumers were measured by statistical analysis of the scores obtained from the response of organoleptic taste panel. The sample containing $1.84 \%$ ginger powder was considered the best in overall acceptability.
\end{abstract}

\section{Introduction}

Commercially obtainable ginger is considered as the spice all over the world in fresh, powdered and paste form (Akpinar and Toraman, 2016). There are forty-five unstable elements in dried $\left(60^{\circ} \mathrm{C}\right)$ ginger-like $\alpha$ zingiberene $(18.28 \%), \alpha$-farnesene $(10.73 \%) \quad$ and geranial (12.42\%) etc. (Utama-Ang, 2019). This medicinal herb has abundant pharmacological and nutraceuticals properties such as gingerols, unstable critical fat and stable oleoresin, shogaols, monoterpenoids, sesquiterpenoids, phenolic contents and a great amount of antioxidant elements which performances as anti-inflammatory, immunomodulatory, therapeutic, antimicrobial functions etc. (An et al., 2016; Tohma et al., 2016; Srinivasan, 2017). It performs as the anticancer material for abounding different elements like vallinoids viz; 6-gingerol and 6-paradol, shogaols, zingerone, and galanals A and B (Shukla and Singh 2007).

Fresh gingers usually contain $85-95 \%$ water which reduces the shelf life and causes massive postharvest damages by losing beneficial constituents (Karabacak et $a l ., 2018)$. These can be escaped by producing ready-toeat ginger foodstuffs like refreshing drinks which are very advantageous for our body against various harmful microorganisms (Beristain-Bauza et al., 2019). Sorption behavior is analyzed to estimate the physical state of food materials in various conditions (Welti-Chanes, 2007). There are various developed empirical, semiempirical, or theoretical models to compare the water sorption in food materials among these GAB and BET are very well known. Moisture sorption properties of ginger will serve as valuable evidence to estimate the shelf life and for appropriate preservation in powder formed. In definite temperatures, moisture sorption isotherms specify the water-binding of material at equilibrium and different water activities. So, sorption isotherm may be the most important element for the perceptive dehydration method according to the elimination of majority water content from ginger. Different value-added ginger-based foods may be produced easily by drying and modifying the processing steps. Dried ginger can be utilized for manufacturing 
ginger spices, medicine and herbal cosmetics as well as foods with ginger flavor such as soft drinks and candies (An et al., 2016).

The consumption of dried ginger powder may decrease the respiratory interchange proportions as well as indorse fat exploitation by escalating the oxidation of fat (Miyamoto et al., 2015). Due to its anti-inflammatory activity endurance runners take $500 \mathrm{mg}$ ginger powder capsules (Mao et al., 2019) and overweight females can decrease the body mass index by taking $2 \mathrm{~g}$ ginger powder per day (Ebrahimzadeh Attari et al., 2015). As the refreshing drink from ginger retains antioxidant prospective with zero fat, vitamin $\mathrm{C}$ and outstanding sensuous characteristics maintaining six months shelf life (Wadikar and Premavalli, 2012). Therefore, powder can be prepared from dried ginger for formulating the drinks along with other suitable constituents. Therefore, the objectives of this study were to analyze the sorption and drying behavior of ginger and to find out the suitable formulations of ginger based drink and organoleptic acceptability of the developed product.

\section{Materials and methods}

\subsection{Raw materials and chemicals}

The fresh ginger was analyzed as per the methods of AOAC (2012) and Ranganna (2003). Citric acid, sodium hydroxide, 2-6 dichlorophenol indophenol, sulphuric acid, hydrochloric acid, Potassium sulphate etc. were reagent grade to conduct the respective tests. Different food-grade ingredients such as sugar, citric acid, thickening agents (carboxymethyl cellulose-CMC), preservative (sodium benzoyte) were mainly used for the preparation of drink along with ginger powder. These were collected in mint condition from the laboratory of the department of Food Technology and Rural Industries (FTRI), Bangladesh Agricultural University (BAU).

\subsection{Sorption isotherm studies}

The technique was performed by setting a slight precisely measured $3 \mathrm{~g}$ ginger powder in a formerly measured crucible in a desiccator that is upholding at an identified relative humidity with the saturated salt solutions. The desiccators were evacuated to less than 50 $\mathrm{mm} \mathrm{Hg}$ and in different intermissions. Then the moisture percentage was estimated. The moisture sorption properties of powdered ginger were evaluated in atmospheric temperature at several (0.11-0.93) water activity $\left(a_{w}\right)$ circumstances in void desiccators. In this method nine saturated salt solutions were made by using nine different salts such as $\mathrm{LiCl}$ (Lithium Chloride), $\mathrm{KC}_{2} \mathrm{H}_{3} \mathrm{O}_{2} \quad$ (Potassium Acetate), $\mathrm{MgCl}_{2} \cdot 6 \mathrm{H}_{2} \mathrm{O}$ (Magnesium Chloride), $\mathrm{K}_{2} \mathrm{CO}_{3}$ (Potassium Carbonate),
$\mathrm{Mg}\left(\mathrm{NO}_{3}\right)_{2} \cdot 6 \mathrm{H}_{2} \mathrm{O}$ (Magnesium Nitrate), $\mathrm{CaCl}_{2}$ (Calcium Chloride), $\mathrm{NaCl}$ (Sodium Chloride), $\mathrm{KCl}$ (Potassium Chloride) and $\mathrm{KNO}_{3}$ (Potassium Nitrate) in which corresponding $\mathrm{a}_{\mathrm{w}}$ were $0.11,0.20,0.33,0.44,0.52,0.68$, $0.75,0.85$ and 0.93 respectively.

\subsection{BET and GAB Model}

To determine the MMC and definite superficial regions of dehydration foodstuffs GAB, BET models are extensively used (Kim et al., 1991). Among these BET equations are applied widely than the other relevant models to explain the moisture sorption isotherms (Menkov et al., 2005).

$$
\text { The BET equation is: } \frac{\mathrm{a}_{\mathrm{W}}}{\left(1-\mathrm{a}_{\mathrm{W}}\right) \mathrm{m}}=\frac{1}{\mathrm{~m}_{\mathrm{0}} \mathrm{c}}+\frac{\mathrm{c}-1}{\mathrm{~m}_{\mathrm{D}} \mathrm{c}} \mathrm{a}_{\mathrm{w}}
$$

Where $\mathrm{a}_{\mathrm{w}}=$ Water activity, $\mathrm{m}=$ moisture value in dry basis $(d b)$ at $a_{w}, m_{0}=$ monolayer moisture value $(d b), C=$ Isotherm temperature reliance coefficient (energy constant).

The GAB is a semi-theoretical multi-molecular, localized homogeneous adsorption and a three-parameter versatile model (Van den Berg, 1985) that is expressed as follows:

$$
\frac{W}{W_{\mathrm{m}}}=\frac{\mathrm{Cl} w_{W}}{\left(1-\mathrm{ka}_{W}\right)\left(1-\mathrm{ka}_{W}+C \mathrm{a}_{W}\right)}
$$

Where $\mathrm{W}=$ Equilibrium moisture fraction $(\mathrm{db}), \mathrm{W}_{\mathrm{m}}=$ MMC (db); $\mathrm{C}=$ Guggenheim constant, $\mathrm{k}=$ Factor correcting properties of multilayer with respect to the bulk liquid. The succeeding method was suggested by Bizot (1983) to fit data on $\mathrm{a}_{\mathrm{w}}$ and equilibrium moisture content (EMC). Alhamdan and Hassan (1999) reported that this model is acceptable to explain the investigational data for $a_{w}$ until 0.90. Equation 2 may be modified in case of higher $\mathrm{a}_{\mathrm{w}}$ (Schuchmann et al., 1990) as follows:

$$
\begin{aligned}
& \frac{\mathrm{a}_{\mathrm{W}}}{\mathrm{W}}=\alpha \mathrm{a}_{\mathrm{ww}}{ }^{2}+\beta \mathrm{a}_{\mathrm{w}}+\gamma \\
& \text { Where; } \alpha=\frac{k}{\mathrm{w}_{\mathrm{m}}}\left(\frac{1}{\mathrm{c}}-1\right) ; \beta=\frac{k}{\mathrm{w}_{\mathrm{m}}}\left(1-\frac{2}{\mathrm{c}}\right) \text { and } \gamma=\frac{1}{\mathrm{w}_{\mathrm{m}} c k}
\end{aligned}
$$

The EMC and $\mathrm{a}_{\mathrm{w}}$ are reverted by applying equation 3 and the values of these coefficients $\alpha, \beta$, and $\gamma$ can be attained. By using $\alpha, \beta$, and $\gamma$, the values of $\mathrm{k}, \mathrm{w}$, and $\mathrm{C}$ are found.

\subsection{Mechanical drying}

Mechanical thin-layer drying technique was used for the dehydration of ginger (cabinet dryer, Model No.:1816, USA) in $0.6 \mathrm{~m} / \mathrm{sec}$ constant airspeed. Fresh ginger slices of 3,5 and $7 \mathrm{~mm}$, were placed in numbered trays and drying commenced at $60^{\circ} \mathrm{C}$ temperature. $\mathrm{MC}$ of samples during drying was determined by gravimetric method from initial known MC. Again, to determine the effect of temperature on the rate of drying $5 \mathrm{~mm}$ slices were dried at different temperatures such as $55^{\circ} \mathrm{C}, 60^{\circ} \mathrm{C}$ 
and $65^{\circ} \mathrm{C}$. To determine the kinetics of one major face drying the following equation was used (Brooker et al., 1974):

$$
M R=\frac{M_{\mathrm{r}}-\mathrm{M}_{\mathrm{e}}}{\mathrm{M}_{\mathrm{0}}-\mathrm{M}_{\mathrm{e}}}=\frac{8}{\pi^{2}} \sum_{\mathrm{n}=\mathrm{o}}^{\infty} \frac{1}{(2 \mathrm{n}+1)^{\mathrm{2}}} \operatorname{Exp} \cdot\left[\frac{-(2 \mathrm{n}+1)^{\mathrm{a}} \pi^{\mathrm{s}} \mathrm{D}_{\mathrm{e}} \mathrm{t}}{\mathrm{1}^{\mathrm{s}}}\right]
$$

For lower amount of $\mathrm{M}_{\mathrm{e}}$ and for moisture ratio $<0.6$ equation 4 moderated to:

$$
\frac{M_{t}}{M_{0}}=\frac{8}{\pi^{2}} e^{-\pi^{2} D_{\theta} t / l^{2}}=\frac{8}{\pi^{2}} e^{-m t}
$$

Where $\mathrm{l}=$ half thickness, $\mathrm{m}=\frac{\pi^{\mathrm{s}} \mathrm{D}_{e}}{\mathrm{l}^{\mathrm{a}}}=$ Drying rate constant $\left(\mathrm{s}^{-1}\right)$

Rearranging equation 5 gives;

$$
\ln \frac{M_{t}}{M_{0}}=\ln \frac{8}{\pi^{2}}-m t
$$

Where $\mathrm{M}_{\mathrm{t}}=$ Moisture content $(\mathrm{db})$ at any time, $\mathrm{M}_{0}=$ Initial moisture percentage $(\mathrm{db}), \mathrm{t}=$ Duration, $\mathrm{D}_{\mathrm{e}}=$ Effective diffusion coefficient. Accordingly, if $\ln (\mathrm{MR})$ are plotted against time (t) a straight pick would be found. $D_{e}$ can be intended from the $m$ value that is obtained from regression line slope which has an Arrhenius form correlation in the corporation of absolute temperature, $\mathrm{T}_{\mathrm{abs}}\left({ }^{\circ} \mathrm{K}\right)$ (Okos et al., 2007). This correlation may be stated by the given formula:

$$
\frac{d \ln D_{e}}{d\left(T_{a b s}\right)}=\frac{E_{a}}{R T_{a b s} 2} \text { or, } \ln D_{e}=\ln D_{o}-\frac{E_{a}}{R T_{a b s}}
$$

Where $\mathrm{D}_{0}=$ Constant of integration furthermore it can be termed as frequency factor for expressing the Arrhenius formula, $E_{a}=$ Activation energy for water diffusion (cal/g.mole), $\mathrm{R}=$ Ideal Gas constant (cal/ g.mole ${ }^{\circ} \mathrm{K}$ ). Equation 7 indicates that placing the $\mathrm{D}_{\mathrm{e}}$ against the converse of $\mathrm{T}_{\mathrm{abs}}$ on semi-logarithmic coordinates which direct to estimate $E_{a}$ of water throughout drying.

The semi-theoretical formula (equation 5) reveals that $\mathrm{m}$ is the function of thickness square of the sample through:

$$
m=\frac{\pi^{2} D_{e}}{l^{a}}
$$

Emblematically, it can be expressed by:

$$
\mathrm{m}=\mathrm{A} .1^{-\mathrm{n}} \text { or } \log \mathrm{m}=\log \mathrm{A}-\mathrm{n} \log (\mathrm{l})
$$

The given equations exhibit that when outer confrontation to mass was minor with coincident heat and mass transition impacts are considered then the index value of power law formula would be two nevertheless the mentioned situation could not always be contented along with practical $\mathrm{n}$ value would be almost or lower than two (Islam, 1980).

\subsection{Formulation of ginger drink}

A total of five different formulations of $100 \mathrm{~g}$ drinks were formulated coded as S-1, S-2, S-3, S-4 and S-5; where ginger was used $11 \%$ (juice), $1.84 \%$ (powder), $2.34 \%$ (powder), $2.85 \%$ (powder) and $3.37 \%$ (powder) respectively. The other ingredients Sugar, Citric acid,
Sodium benzoate and CMC remained constant as $13 \%$, $0.25 \%, 0.04 \%$ and $0.4 \%$ respectively. The calculated amount of sugar and citric acid and $\mathrm{H}_{2} \mathrm{O}$ were weighed accurately and mixed for each formulation. It was boiled for about 3 to 5 mins to prepare the syrup. The prepared syrup was filtered through cheese cloth. The calculated amount of the ginger powder was then mixed with this prepared syrup. The mixture was then stirred thoroughly for well mixing and $\mathrm{CMC}$ added after adding the powder. The drink was heated to about $63^{\circ} \mathrm{C}$ for pasteurization. The prepared drink was homogenized at $2500 \mathrm{rpm}$ for $15 \mathrm{mins}$. The prepared drink as cooled down to about 28 to $30^{\circ} \mathrm{C}$ and then calculated amount of sodium benzoate $\left(\mathrm{C}_{6} \mathrm{H}_{5} \mathrm{COONa}\right)$ was added and mixed thoroughly again with each of the products by a wiring blender. The well mixed prepared drink was poured into in to hot water washed bottles through hot water washed funnels keeping head space about $2 \mathrm{~cm}$. The bottles were corked and sealed tightly. The sealed bottles were then labeled indicating the amount of formulations, the name of the products, the number of sample etc. The final products were stored in a room and refrigerated temperature.

\subsection{Sensory evaluation}

The symmetry and the characteristics of drinks were evaluated for color, flavor, sweetness and overall acceptability through a testing panel. The panelists were selected from the teachers, students and employees of the department of FTRI, BAU, Mymensingh-2202, Bangladesh. Preference was made by score points. The score points were selected as follows: $9=$ Like extremely; $8=$ Like very much; $7=$ Like moderately; $6=$ Like slightly; $5=$ Neither like or dislike; $4=$ Dislike slightly; 3 = Dislike moderately; 2 = Dislike very much and $1=$ Dislike extremely. The preference differences were evaluated by statistical analysis of the data for variance and consequently Duncan's Multiple Range Test (DMRT). Procedures of the statistical analysis system (SAS, 1985) were used.

\section{Results and discussion}

\subsection{Chemical analysis}

The composition of ginger may vary due to varietals differences, variations of soil, growing conditions, climate, stage of maturity, the time elapsed between harvesting and analysis (Shirshir et al., 2012). The amount of MC, total solids, ash, protein, carbohydrate, ascorbic acid, reducing sugar, acidity and $\mathrm{pH}$ of the selected fresh ginger were $83.89 \%, 16.11 \%, 0.80 \%$, $1.98 \%, 12.73 \%, 6 \mathrm{mg} / 100 \mathrm{~g}, 0.98 \%, 0.12 \%$ and 6.33 respectively in wet basis. The analyzed chemical compositions were nearly similar to those stated by 
Rahman et al. (2013).

\subsection{Sorption behavior of ginger}

The water sorption isotherm of dried ginger powder was developed in declining moisture content (MC) against $\mathrm{a}_{\mathrm{w}}$ at a constant temperature. The isotherm is shown in Figure 1 seems S-shaped and may be categorized as type II (Iglesias and Chirife, 1975). These types of foodstuffs are estimated to possess rich carbohydrate like ginger (Bandyopadhyay et al., 1987). The EMC of the samples increased as $a_{w}$ increased at a constant temperature. Slopes of the isotherms were gentle at lower $a_{w}$ than 0.55 where relatively lesser moisture was absorbed for a greater rise in $\mathrm{a}_{\mathrm{w}}$.

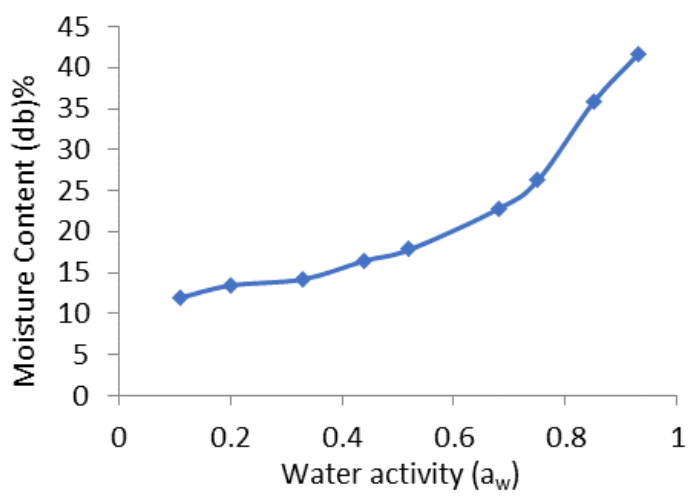

Figure 1. Sorption isotherm of ginger

The moisture absorption tendency was low at $\mathrm{a}_{\mathrm{w}}$ of below 0.52 but the sample started absorbing a higher amount of moisture at $\mathrm{a}_{\mathrm{w}}$ above this level (Alakali et al., 2009). The higher EMC is given in ginger at 0.6 and 0.65 $\mathrm{a}_{\mathrm{w}}$ may be related to the presence of reducing sugar. Thus ginger having MC $20.34 \%$ and $21.896 \%$ (at $a_{w} 0.60$ and 0.65 respectively) could be advantageously preserved at higher MC.

\subsubsection{Analysis of sorption isotherm according to BET and GAB Model}

To calculate MMC $\left(\mathrm{w}_{\mathrm{o}}\right)$ according to BET model equation 1 was used (only data up to aw of 0.44 ) and $\mathrm{w}_{\mathrm{o}}$ represent the optimal moisture for maximum storage stability on the dry state. The equation obtained from Figure 2 is:

$$
\mathrm{a}_{\mathrm{w}} /\left(1-\mathrm{a}_{\mathrm{w}} / \mathrm{w}\right)=12.22 \mathrm{a}_{\mathrm{w}}+0.447
$$

Monolayer value and energy constant (C) of ginger were evaluated from the slope and the intercept of Figure 2 . The MMC and energy constant of ginger were found to be $6.57 \mathrm{~g}$ per $100 \mathrm{~g}$ solid (Table 1) and $15.334 \mathrm{cal} / \mathrm{g}$ mol respectively from BET equation.

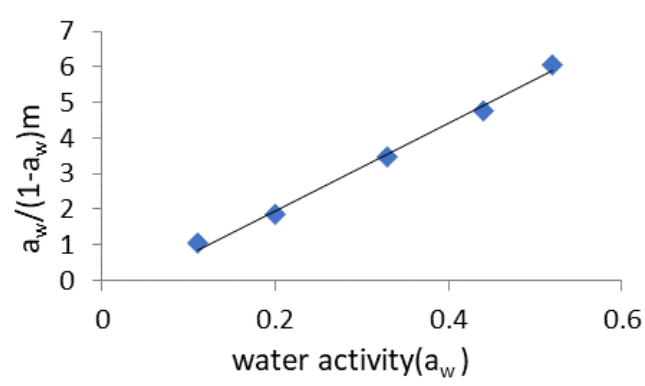

Figure 2. BET equation for sorption isotherm

After fitting data, a figure (Figure 3) was developed and an equation 11 to determine the MMC of ginger was obtained. The equation is:

$$
\mathrm{a}_{\mathrm{w}} / \mathrm{w}=-8.124 \mathrm{a}_{\mathrm{w}}{ }^{2}+10.02 \mathrm{a}_{\mathrm{w}}-0.130
$$

Where $\alpha=-8.124, \beta=10.02$ and $\gamma=-0.130$

From the developed Equation 11 and Figure 3, the coefficients $\alpha, \beta$, and $\gamma$ were found to be $-8.124,10.02$ and -0.13 respectively (Table 1 ). By putting the value of $\mathrm{k}=0.93$ the MMC was found to be $7.99 \mathrm{~g}$ water per $100 \mathrm{~g}$ solid and energy constant was found to be 3.8 .

BET equation gave a much smaller value of $\mathrm{MMC}$ of ginger compared to that obtained from the $\mathrm{GAB}$ equation (Table 1). Timmermann (2003) stated that the GAB monolayer value is every time greater than the BET monolayer value while energy constants for GAB model are lower than that of BET equation.

\subsection{Analysis of drying kinetics}

\subsubsection{Effect of thickness on drying time}

The results were analyzed by using Equation 5 and moisture ratio (MR) against drying time (hr) was plotted on a semi-log graph paper is shown in Figure 4. For three different thicknesses, three equations were developed. These are:

$$
\begin{aligned}
& M R=1.037 \mathrm{e}^{-0.41 \mathrm{t}}(\text { for } 7 \mathrm{~mm} ; \mathrm{t}=\mathrm{hr}) \\
& \mathrm{MR}=0.985 \mathrm{e}^{-0.47 \mathrm{t}}(\text { for } 5 \mathrm{~mm} ; \mathrm{t}=\mathrm{hr}) \\
& M R=0.92 \mathrm{e}^{-0.49 t}(\text { for } 3 \mathrm{~mm} ; \mathrm{t}=\mathrm{hr})
\end{aligned}
$$

The thickness has a profound influence on drying time (Figure 4) and that the thickness of samples increases the drying time to a specific moisture ratio also increases with resultant decreases in drying rate constant. Time to dry MC corresponding to $\mathrm{a}_{\mathrm{w}} 0.65(21.9 \mathrm{Mc} \mathrm{db})$ of $3 \mathrm{~mm}$ thick slice required the least $6.33 \mathrm{hrs}$, followed by $5 \mathrm{~mm}$ thick slice, while the highest time ( $7.85 \mathrm{hrs})$ is required to dry $7 \mathrm{~mm}$ thick ginger slice at $60^{\circ} \mathrm{C}$. Thus by drying $7 \mathrm{~mm}$ thick sample instead of $3 \mathrm{~mm}, 50 \%$ time can be saved.

Table 1. Constants and co-efficient for BET and GAB equations

\begin{tabular}{ccccccc}
\hline Model & MMC $(\mathrm{g} / 100 \mathrm{~g})$ & Constant $\left({ }^{\circ} \mathrm{C}\right)$ & $\alpha$ & $\beta$ & $\gamma$ & $\mathrm{R}$ \\
\hline $\mathrm{BET}$ & 6.57 & 15.334 & - & - & - & 0.993 \\
$\mathrm{GAB}$ & 7.99 & 3.28 & -8.124 & 10.02 & -0.13 & 0.988 \\
\hline
\end{tabular}




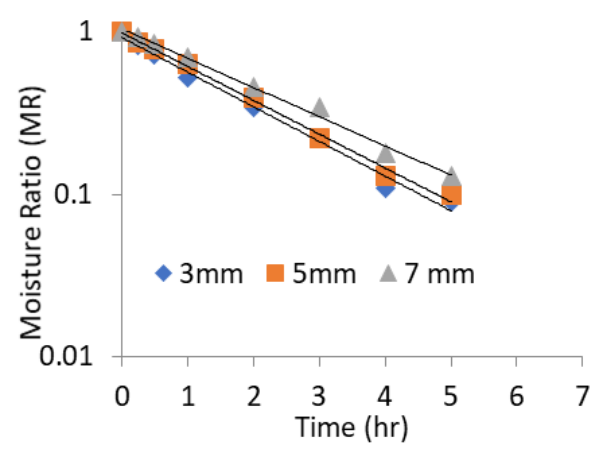

Figure 4. Influence of thickness on drying rate at $60^{\circ} \mathrm{C}$

The drying rate constants were determined by regression analysis and were plotted against sample thickness on log-log coordinates (Figure 5).

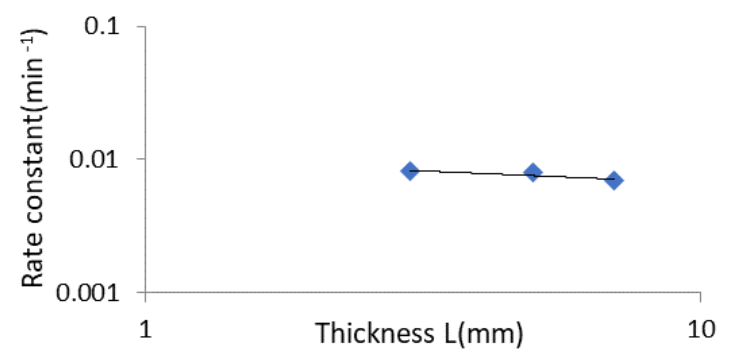

Figure 5. Influence of thickness on drying rate constant at $60^{\circ} \mathrm{C}$

The plot in Figure 5 shows that the relationship between sample thickness and drying rate constant can be represented by power law equation as follows:

$$
\mathrm{m}=0.010 L^{-0.17 \mathrm{t}}
$$

Where $\mathrm{m}=$ drying rate constant $\left(\mathrm{min}^{-1}\right)$ and $\mathrm{L}=$ sample thickness $(\mathrm{mm})$.

From the above equation, it is seen that the value of the index ' $n$ ' for ginger is 0.17 which is less than 2 that indicates that internal resistance to mass transfer is almost negligible compared to external resistance to mass transfer. This means that higher airflow rates would give higher rates of moisture removal. Furthermore, at low air velocity within this range of thickness, a slight increase in thickness may show no disadvantage as per as throughput is concerned as noted by Islam (1980).

\subsubsection{Influence of temperature on drying time}

A mechanical drier was used to dry the $5 \mathrm{~mm}$ thick ginger slices at three different air-dry bulb temperature $\left(55,60\right.$ and $\left.65^{\circ} \mathrm{C}\right)$. The experimental drying data were analyzed using Equation 5 and shown in Table 2.

The plots of moisture ratio against drying time were made on semi-log graph paper (Figure 6) and the following regression equations were developed:

$$
\begin{aligned}
& M R=1.013 \mathrm{e}^{-0.45 \mathrm{t}}\left(\text { for } 55^{\circ} \mathrm{C} ; \mathrm{t}=\mathrm{hr}\right) \\
& M R=0.985 \mathrm{e}^{-0.47 \mathrm{t}}\left(\text { for } 60^{\circ} \mathrm{C} ; \mathrm{t}=\mathrm{hr}\right) \\
& M R=0.974 \mathrm{e}^{-0.53 \mathrm{t}}\left(\text { for } 65^{\circ} \mathrm{C} ; \mathrm{t}=\mathrm{hr}\right)
\end{aligned}
$$

When the temperature is increased, the drying rate constant is also increased (Figure 6). At the same time due to increase in temperature for a certain MC, drying time was decreased. For example, time to dry $5 \mathrm{~mm}$ thick ginger slice at to $60^{\circ} \mathrm{C} 21.9 \% \mathrm{MC} \mathrm{db}$ (at aw 0.65 ) is 6.75 hrs and $6 \mathrm{hrs}$ at $65^{\circ} \mathrm{C}$. Thus $13 \%$ time can be saved by drying at $65^{\circ} \mathrm{C}$ instead of $60^{\circ} \mathrm{C}$. It is also noticeable that at falling rate stage ginger pieces dry. Loha et al. (2012) evaluated air drying properties in a forced convective cabinet dryer and thermal conductivity measurement of sliced ginger and stated this same statement.

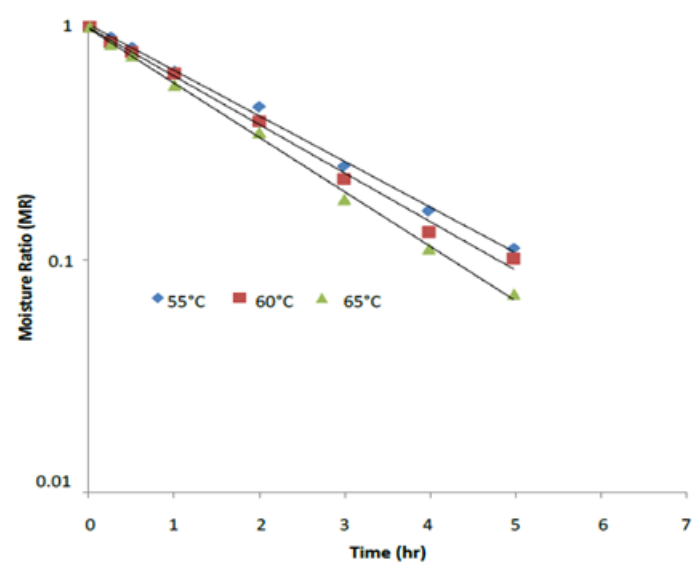

Figure 6. Effect of temperature on drying rate for $5 \mathrm{~mm}$ thick ginger

From the drying rate constants, determined by regression equations (Figure 6), the diffusion coefficients were calculated. By plotting diffusion coefficient (De) versus inverse absolute temperature $\left(1 / \mathrm{T}_{\mathrm{abs}}\right.$. $)$ in a semilog scale a regression line was drawn (Figure 7). From the slope of the resultant straight line, activation energy (Ea) for De for ginger was calculated and found to be $3.735 \mathrm{kcal} / \mathrm{g}$-mole. The dependence of the diffusion coefficient on absolute temperature can be represented

Table 2. Drying rate constants and diffusion coefficient under different drying conditions

\begin{tabular}{ccccc}
\hline $\begin{array}{c}\text { Thickness } \\
(\mathrm{mm})\end{array}$ & $\begin{array}{c}\text { Temperature } \\
\left({ }^{\circ} \mathrm{C}\right)\end{array}$ & $\begin{array}{c}\text { Rate constant } \\
\left(\text { hour }^{-1}\right)\end{array}$ & $\begin{array}{c}\text { Diffusion co-efficient (De) } \\
\left(\mathrm{cm}^{2} / \mathrm{s}\right)\end{array}$ & $\begin{array}{c}\text { Activation energy } \\
(\mathrm{kcal} / \mathrm{g}-\mathrm{mole})\end{array}$ \\
\hline 3 & & 0.49 & $1.23 \times 10^{-6}$ & - \\
5 & 60 & 0.474 & $3.335 \times 10^{-6}$ & - \\
7 & & 0.414 & $5.709 \times 10^{-6}$ & - \\
& 55 & 0.45 & $3.166 \times 10^{-6}$ & - \\
5 & 60 & 0.474 & $3.335 \times 10^{-6}$ & 3.735 \\
& 65 & 0.534 & $3.757 \times 10^{-6}$ & - \\
\hline
\end{tabular}


as:

$$
\mathrm{De}=0.001 \mathrm{e}^{-1881 \mathrm{t}}
$$

Where; De $=$ Diffusion coefficient $\left(\mathrm{cm}^{2} / \mathrm{s}\right)$ and $\mathrm{T}_{\mathrm{abs}}=$ absolute temperature

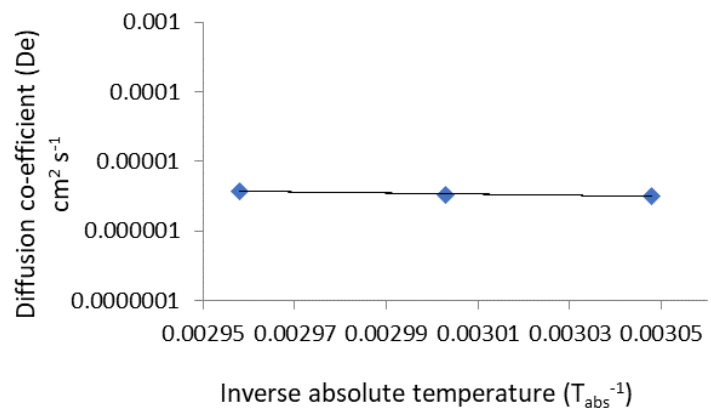

Figure 7. Effect of temperature on diffusion coefficient of 5 $\mathrm{mm}$ thick fresh ginger

\subsection{Development of drink from powdered ginger}

Utama-Ang (2019) reported that ginger powder produced from drying at $60^{\circ} \mathrm{C}$ temperature is appropriate. Hoque et al. (2013) recommended that superior dried foods can be obtained from the sliced ginger rhizome which is dried below $70^{\circ} \mathrm{C}$ temperature. By considering the nutrients loss and product stability ginger powder dried at $60^{\circ} \mathrm{C}$ in the cabinet dryer was used for the preparation of the drink. Powdered ginger having the MC- $13.1 \%$, total solid- $86.9 \%$, ash- $0.89 \%$, protein-5.32\%, carbohydrate- $78.94 \%$, ascorbic acid-3.52 $\mathrm{mg} / 100 \mathrm{~g}$, acidity- $1.01 \%$ and $\mathrm{pH}-5.2$ in wet basis.

\subsubsection{Chemical composition of formulated ginger drink}

It mentioned here that S-1 using $11 \%$ ginger juice was judged to the best sample. After preparation of the products, the chemical compositions were determined. The compositions of the products have been shown in Table 3 .

Table 3. Chemical composition of the formulated drinks

\begin{tabular}{cccc}
\hline Samples & Moisture (\%) & Ash (\%) & Acidity (\%) \\
\hline S-1 & 84.6 & 0.815 & 0.211 \\
S-2 & 83.61 & 0.817 & 0.256 \\
S-3 & 83.22 & 0.82 & 0.256 \\
S-4 & 82.7 & 0.83 & 0.307 \\
S-5 & 82.29 & 0.831 & 0.331 \\
\hline
\end{tabular}

\subsubsection{Sensory evaluation of ginger drink}

After preparing the drink the flavor, color, sweetness and overall acceptability were evaluated by a panel of 10 judges. The mean scores of the samples are given in Table 4 after the statistical analysis.

A two-way analysis of variance indicated that all the sensory attributes of different samples were significantly $(p<0.01)$ different and thus the sensory attributes of the samples showed various degrees of acceptability, where the superscripts ( $a, b$ and $c)$ were correlation factors of the DMRT test. The color of the different formulation was not equally acceptable. It is seen that S-2 was the most preferred. The color changes initiated by heat processing may have affected the non-enzymatic browning of food and the deterioration of pigment in the food (Youssef et al., 2014). In case of flavor preference, the S-3 was the most preferred. The sweetness of S-2 was the most preferred. S-2 was the most preferred one securing 7.5 for overall acceptability. So, from the above discussion, S-2 (7.5) was the most acceptable drink and ranked as "like moderately". Except that the samples S-3 and S-5 secured score 7.40 and 7.0 respectively were also ranked as "like moderately "while the other two samples S-4 and S-1 (score 6.8 and 6.6) were ranked as "like slightly".

Table 4. Mean sensory score of ginger drink for different samples

\begin{tabular}{|c|c|c|c|c|}
\hline \multirow[b]{2}{*}{ Sample } & \multicolumn{4}{|c|}{ Mean score } \\
\hline & $\stackrel{\rho}{\circ}$ & $\begin{array}{l}\frac{T}{\overrightarrow{2}} \\
\stackrel{0}{2} \\
\stackrel{0}{G}\end{array}$ & 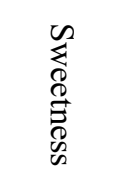 & 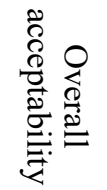 \\
\hline S-1 & $6.300^{c}$ & $6.800^{\mathrm{bc}}$ & $6.300^{c}$ & $6.600^{\mathrm{b}}$ \\
\hline $\mathrm{S}-2$ & $7.700^{\mathrm{a}}$ & $7.600^{\mathrm{a}}$ & $7.300^{\mathrm{a}}$ & $7.500^{\mathrm{a}}$ \\
\hline $\mathrm{S}-3$ & $7.500^{\mathrm{a}}$ & $7.700^{\mathrm{a}}$ & $7.000^{\mathrm{ab}}$ & $7.400^{\mathrm{a}}$ \\
\hline S-4 & $6.900^{\mathrm{b}}$ & $6.400^{c}$ & $6.500^{\mathrm{bc}}$ & $6.800^{\mathrm{ab}}$ \\
\hline$S-5$ & $7.200^{\mathrm{ab}}$ & $7.400^{\mathrm{ab}}$ & $6.800^{\mathrm{abc}}$ & $7.000^{\mathrm{ab}}$ \\
\hline
\end{tabular}

Similar superscripts within the same column indicate no significant difference at $\mathrm{p}>0.01$.

\section{Conclusion}

Ginger can be dried by adopting feasible temperature and process for producing powder to prevent the huge postharvest losses. Ginger is preserved as powder form by reducing $\mathrm{MC}$ to an acceptable level of EMC corresponding $0.65 \mathrm{a}_{\mathrm{w}}$ using the drying method. Health benefited drink can be prepared by using powdered ginger along with other associate ingredients. It was found that the drink containing $1.84 \%$ ginger powder, $13 \%$ sugar, $0.25 \%$ citric acid, $0.04 \%$ sodium benzoate and $0.4 \% \mathrm{CMC}$ was the most acceptable. This powderbased ginger drink may be used for the treatment of stomach disorders, nausea, diarrhea, colic, arthritis, heart conditions, menstrual period, dyspepsia, rheumatism and flu-like symptoms, bronchitis etc.

\section{Conflict of interest}

The authors declare no conflict of interest. 


\section{Acknowledgement}

The authors expresses gratitude to the National Science and Technology (NST) fellowship under the Ministry of Science and Technology (MoST), Bangladesh for providing the fund to carry out this research.

\section{References}

Akpinar, E.K. and Toraman, S. (2016). Determination of drying kinetics and convective heat transfer coefficients of ginger slices. Heat and Mass Transfer, 52(10), 2271-2281. https:// doi.org/10.1007/s00231-015-1729-6

Alakali, J., Irtwange, S.V. and Satimehin, A. (2009). Moisture adsorption characteristics of ginger slices. Ciência E Tecnologia de Alimentos, 29(1), 155-164. https://doi.org/10.1590/S0101-20612009000100024

Alhamdan, A.M. and Hassan, B.H. (1999). Water sorption isotherms of date paste as influenced by date cultivar and storage temperature. Journal of Food Engineering, 39(3), 301-306. https:// doi.org/10.1016/S0260-8774(98)00170-8

An, K., Zhao, D., Wang, Z., Wu, J., Xu, Y. and Xiao, G. (2016). Comparison of different drying methods on Chinese ginger (Zingiber officinale roscoe): Changes in volatiles, chemical profile, antioxidant properties and microstructure. Food Chemistry, 197(Part B), 1292-1300.

j.foodchem.2015.11.033

AOAC. (2012). Official Methods of Analysis of Analytical Chemists. $19^{\text {th }}$ ed. Washington DC, USA: AOAC.

Bandyopadhyay, S., Weisser, H.G. and Lonein, M. (1987). Water adsorption isotherms of food at high temperature. Lebensmittel-Wissenschaft-undTechnologie, 13, 182-155.

Beristain-Bauza, S.D.C., Hernández-Carranza, P., CidPérez, T.S., Ávila-Sosa, R., Ruiz-López, I.I. and Ochoa-Velasco, C.E. (2019). Antimicrobial activity of ginger (Zingiber officinale) and its application in food products. Food Reviews International, 35(5), 407-426. doi.org/10.1080/87559129.2019.1573829

Bizot, H. (1983). Using the GAB model to construct sorption isotherm. In Jowitt, R., Escher, F., Hollstorm, B., Meffet, H.F.T., Spiess, W.E.L. and Voss, G. (Eds). Physical Properties of Foods, p. 4554. London: Applied Science Publishers.

Brooker, D.B., Bakker, F.W. and Hall, C.W. (1974). Drying of cereal grains. $1^{\text {st }}$ ed. USA: AVI Publication Company Inc.

Ebrahimzadeh Attari, V., Ostadrahimi, A., Asghari
Jafarabadi, M., Mehralizadeh, S. and Mahluji, S. (2015). Changes of serum adipocytokines and body weight following Zingiber officinale supplementation in obese women: a RCT. European Journal of Nutrition, 55(6), 2129-2136. ttps:// doi.org/10.1007/s00394-015-1027-6

Hoque, M., Bala, B., Hossain, M. and Uddin, M.B. (2013). Drying Kinetics of Ginger Rhizome (Zingiber officinale). Bangladesh Journal of Agricultural Research, 38(2), 301-319. https:// doi.org/10.3329/bjar.v38i2.15892

Iglesias, H.A. and Chirife, J. (1975). Water sorption isotherms of sugar-beet roots. International Journal of Food Science and Technology, 10(3), 299-308. https://doi.org/10.1111/j.1365-2621.1975.tb00033.x

Islam, M.N. (1980). Use of solar energy for development of shelf-stable potato products suitable for Bangladesh. Copenhagen: Royal Veterinary and Agricultural University, $\mathrm{PhD}$ Dissertation.

Karabacak, A.Ö., Suna, S., Tamer, C. and Çopur, Ö. (2018). Effects of oven, microwave and vacuum drying on drying characteristics, colour, total phenolic content and antioxidant capacity of celery slices. Quality Assurance and Safety of Crops and Food, 10(2), 193-205. https://doi.org/10.3920/ QAS2017.1197

Kim, H.K., Song, G.Y. and Yam, K.L. (1991). Water sorption characteristics of dried red peppers (Caspsium annum L). International Journal of Food Science and Technology, 29(3), 339-345. https:// doi.org/10.1111/j.1365-2621.1994.tb02075.x

Loha, C., Das, R., Choudhury, B. and Chatterjee, P.K. (2012). Evaluation of Air Drying Characteristics of Sliced Ginger (Zingiber officinale) in a Forced Convective Cabinet Dryer and Thermal Conductivity Measurement. Journal of Food Processing and Technology, 3(6), 23-28. https:// doi.org/10.4172/2157-7110.1000160

Mao, Q.-Q., Xu, X.-Y., Cao, S.-Y., Gan, R.-Y., Corke, H., Beta, T. and Li, H.-B. (2019). Bioactive Compounds and Bioactivities of Ginger (Zingiber officinale Roscoe). Foods, 8(185), 1-21. https:// doi.org/10.3390/foods 8060185

Menkov, N.D. and Durakova, A.G. (2005). Equilibrium Moisture Content of Semi-Defatted Pumpkin Seed Flour. International Journal of Food Engineering, 1 (3), 1-6. https://doi.org/10.2202/1556-3758.1008

Miyamoto, M., Matsuzaki, K., Katakura, M., Hara, T., Tanabe, Y. and Shido, O. (2015). Oral intake of encapsulated dried ginger root powder hardly affects human thermoregulatory function, but appears to facilitate fat utilization. International Journal of 
Biometeorology, 59(10), 1461-1474. https:// doi.org/10.1007/s00484-015-0957-2

Okos, M.R., Campanella, O., Narsimhan, G., Singh, R.K. and Weitnauer, A.C. (2007). Food Dehydration. In Heldman, D.R., Lund, D.B. (Eds.). Handbook of Food Engineering, p. 603-718. London: CRC Press. https://doi.org/10.1201/9781420014372.ch10

Rahman, M.I., Talukder, M.A.I., Rani, L., Saha, K.E. and Nahid, M.S.I. (2013). The effect of processing Techniques on the shelf life, Nutritional and sensory Quality of Ginger (Zingiber officinale) Powder and Paste. Journal of Innovation and Development strategy, 7(3), 60-66.

Ranganna, S. (2003). Hand Book of Analysis of Quality Control for Fruit and Vegetable Products. $2^{\text {nd }} e d$. New Delhi, India: Tata McGraw Hill Publication Company Limited.

SAS. (1985). SAS users guide: Statistics, $5^{\text {th }}$ ed. New York: SAS Institute Incorporation.

Schuchmann, H., Roy, I. and Peleg, M. (1990). Empirical Models for Moisture Sorption Isotherms at Very High Water Activities. Journal of Food Science, 55(3), 759-762. https://doi.org/10.1111/ j.1365-2621.1990.tb05223.x

Shirshir, M.R.I., Hossain, M. and Hossain, M.M. (2012). Processing of Ginger powder, Faculty of AgroIndustrial and Food Process Engineering. Bangladesh Research Publications Journal, 7(3), 277-282.

Shukla, Y. and Singh, M. (2007). Cancer preventive properties of ginger: A brief review. Food Chemical Toxicology, 45(5), 683-690. https://doi.org/10.1016/ j.fct.2006.11.002

Srinivasan, K. (2017). Ginger rhizomes (Zingiber officinale): A spice with multiple health beneficial potentials. Pharma Nutrition, 5(1), 18-28. https:// doi.org/10.1016/j.phanu.2017.01.001

Timmermann, E.O. (2003). Multilayer sorption parameters: BET or GAB values? Colloids and Surfaces A: Physicochemical and Engineering Aspects, 220(2003), 235-260. https:// doi.org/10.1016/s0927-7757(03)00059-1

Tohma, H., Gülçin, İ., Bursal, E., Gören, A.C., Alwasel, S.H. and Köksal, E. (2016). Antioxidant activity and phenolic compounds of ginger (Zingiber officinale Rosc.) determined by HPLC-MS/MS. Journal of Food Measurement and Characterization, 11(2), 556 -566. https://doi.org/10.1007/s11694-016-9423-z

Utama-Ang, N. (2019). Influence of Maturity and Drying Temperature on Antioxidant Activity and Chemical Compositions in Ginger. Current Applied Science and Technology, 19(1), 28-42.
Van den Berg, C. (1985). Development of BET-like models for sorption of water in foods: Theory and relevance. In: Simatos, D. and Multon, J.L. (Eds). Properties of Water in Foods in relation to Food quality and Stability, p. 119-131. Dordretch, The Netherland: Martinus Nijhoff Publishers. https:// doi.org/10.1007/978-94-009-5103-7_8

Wadikar, D.D. and Premavalli, K.S. (2012). Optimization of ginger-based ready-to-drink appetizer by response surface methodology and its shelf stability. Journal of Food Processing and Preservation, 36(6), 489-496. https:// doi.org/10.1111/j.1745-4549.2011.00615.x

Welti-Chanes, J., Guerrero, J.A., Bárcenas, M., Aguilera, J.M., Vergara, F. and Barbosa-Cánovas, G.V. (2007). Glass transition temperature (Tg) and water activity $\left(\mathrm{a}_{\mathrm{w}}\right)$ of dehydrated apple products. Journal of Food Process Engineering, 22(2), 91-101. https:// doi.org/10.1111/j.1745-4530.1999.tb00473.x

Youssef, K.M. and Mokhtar, S.M. (2014). Effect of Drying Methods on the Antioxidant Capacity, Color and Phytochemicals of Portulaca oleracea $L$. Leaves. Journal of Nutrition and Food Sciences, 4 (6), 1-6. https://doi.org/10.4172/2155-9600.1000322 